https://doi.org/10.18778/1509-877X.2020.04.03

\title{
Zalecenia Międzynarodowego Funduszu WALUTOWEGO W PROCESIE REFORMOWANIA POLSKIEGO SYSTEMU PODATKOWEGO
}

Streszczenie. Przejście, z sukcesem, od centralnie planowanej do wolnorynkowej gospodarki wymagało całkowitej przebudowy systemu podatkowego. Od początku MFW pomagał władzom polskim, formułując rekomendacje i techniczne rozwiązania w swoich raportach. Artykuł wskazuje, jak polskie władze były wspomagane przez MFW i w jakim stopniu polskie reformy były kształtowane przez konsensus waszyngtoński. Zalecenia MFW w sprawie reformy podatkowej powinny być analizowane jako integralna część procesu transformacji. Artykuł poddaje badaniu, które z rekomendacji MFW były przyjmowane przez polskie władze i dlaczego niektóre zmiany systemu podatkowego były dalekie od najlepszych praktyk podsuwanych przez MFW. Chociaż od chwili przyjęcia Polski do UE uwaga MFW mniej koncentrowała się na sprawach podatkowych, to jednak pomoc techniczna MFW na polu administracji podatkowej była nieoceniona. W artykule znalazła się ocena ostatniej reformy skarbowej podatku VAT z perspektywy rekomendacji misji technicznej MFW. Ostatnia część artykułu jest poświęcona analizie wyzwań, jakie stoją przed przyszłą współpracą z MFW na polu podatkowym.

Słowa kluczowe: transformacja systemowa, Międzynarodowy Fundusz Walutowy, reformy podatkowe, konsensus waszyngtoński, administracja podatkowa.

* Doradca Prezesa Narodowego Banku Polskiego, e-mail: andrzej.raczko@nbp.pl 
Transformacja systemowa z początku lat dziewięćdziesiątych ubiegłego wieku, której celem było stworzenie sprawnie funkcjonującej gospodarki rynkowej, nie mogła ominąć również systemu podatkowego. W tym przypadku należy mówić nie tyle o przekształceniu, ile o stworzeniu od podstaw całego systemu podatkowego w sensie: legislacyjnym (prawo podatkowe), organizacyjnym (reorganizacja administracji skarbowej), nowego systemu relacji w sprawach podatkowych pomiędzy obywatelem a władzą (zarówno w wymiarze rozstrzygania sporów podatkowych, jak i w odniesieniu do sposobu tworzenia i egzekwowania przepisów podatkowych).

Z punktu widzenia ekonomicznego proces tworzenia systemu podatkowego wymagał zdefiniowania wzorca docelowego, ścieżki przejścia do nowego systemu i określenia dodatkowych czynników, które miały zapewnić spójność reformy z całym procesem transformacji. Względy finansowe (kredyty, negocjacje w sprawie konwersji zadłużenia zagranicznego) oraz umiejętność programowania procesu reform, a także szeroka wiedza ekspercka (misje techniczne) zadecydowały o szerokim korzystaniu z pomocy Międzynarodowego Funduszu Walutowego (MFW) ${ }^{1}$ i Banku Światowego w przygotowaniu i wdrażaniu reform gospodarczych.

Celem niniejszego opracowania jest zarysowanie roli, jaką w procesie tworzenia i rozwoju polskiego systemu podatkowego odegrał Międzynarodowy Fundusz Walutowy. Początkowy proces transformacji systemowej opierał się na koncepcji reform zwanej konsensusem waszyngtońskim. Plany zmian systemu podatkowego powstawały we współpracy z MFW. Fundusz wspierał zmiany w Polsce nie tylko finansowo, ale również poprzez misje eksperckie. Zakończenie pierwszego, najistotniejszego etapu reform nie przerwało dialogu pomiędzy władzami i MFW. Opinia tej instytucji dotycząca stanu gospodarki i prowadzonej polityki gospodarczej, upubliczniana $\mathrm{w}$ formie raportu $\mathrm{z}$ tzw. przeglądu $\mathrm{z}$ artykułu IV statutu organizacji ${ }^{2}$, wpływała na rynki finansowe i krajową opinię publiczną, w związku z czym władze chętnie współpracowały z MFW. Kolejne rządowe projekty reform w wielu aspektach były zbieżne $\mathrm{z}$ rekomendacjami MFW, niestety nie do końca

1 Początkowo szkic reform w Polsce przedstawił J. Sachs (Poland's Jump to the Market Economy, Cambridge, MA 1993), szybko jednak została nawiązana współpraca z MFW (D. Lipton, J. Sachs, Creating a Market Economy in Eastern Europe: The Case of Poland, „Brookings Papers in Economic Activity” 1990, t. 1, s. 75-133).

2 International Monetary Fund, Articles of Agreement, Washington, 1993, s. 5-7. 
proces reformowania kończył się powodzeniem, co znajdowało swój wyraz w opiniach MFW. Pogłębione rekomendacje MFW dotyczące systemu podatkowego były owocem misji eksperckich. Pierwsza fala misji podatkowych (1990-1992) była ściśle związana z wprowadzeniem podstawowych reform określanych mianem planu Balcerowicza, drugą falę misji przeprowadzono w okresie planowania reform podatkowych, ściśle powiązanych z procesem akcesji do Unii Europejskiej (1999), trzecia fala misji zajmowała się problemem ściągalności podatku VAT (2014).

\section{2. „WZORCOWY” SYSTEM PODATKOWY} JAKO ELEMENT KONSENSUSU WASZYNGTOŃSKIEGO

Ukształtowanie konsensusu waszyngtońskiego, jako pakietu reform skierowanych do zadłużonych krajów Ameryki Łacińskiej, przypisuje się instytucjom Bretton Woods ${ }^{3}$. Organizacje te wielokrotnie jednak podkreślały, że nie ma systemu, który pasuje do każdej gospodarki, i dlatego ich rekomendacje są „szyte na miarę”, to znaczy są odpowiednie dla danej gospodarki w danym czasie ${ }^{4}$. Niemniej sposób podejścia do rozwiązywania problemów gospodarczych przez Międzynarodowy Fundusz Walutowy oparty był na modelu efektywnie funkcjonującej gospodarki rynkowej i wizji właściwie prowadzonej polityki gospodarczej. Oczywiście sposób podejścia do reform gospodarczych podlegał adaptacjom, ponieważ organizacja absorbowała wiedzę na temat sposobu działania gospodarek tzw. wschodzącego rynku, makroekonomiczny rdzeń modelu pożądanej gospodarki nie ulegał jednak istotnym zmianom ${ }^{5}$. Z podanych powodów rekomendacje dotyczące polityki podatkowej stają się zrozumiałe, jeśli system podatkowy rozpatruje się jako składową pożądanego modelu gospodarki z właściwą, opartą na kilku priorytetach, polityką gospodarczą ${ }^{6}$.

3 Samą nazwą posłużył się J. Williamson w pracy opublikowanej pierwotnie w kwietniu 1990 r. (What Washington Means by Policy Reform, [w:] Latin American Adjustment: How Much Has Happened, Washington 2002).

${ }_{4}$ M. Guitian, The Unique Nature of the Responsibilities of the International Monetary, IMF Pamphlet Series nr 46, Washington 1992, s. 14-18.

5 A. Krueger, A Continuous Adventure: The Pursuit of Stability and Growth in Modern Economies, Distinguished Lectures Series nr 18, Akademia Leona Koźmińskiego, Warszawa 2006.

${ }^{6}$ S. Gupta, M. Keen, B. Clements, L. Mello, M. Mani, Fiscal Dimensions of Sustainable Development, IMF Pamphlet Series nr 54, Washington 2002. 
Za główny priorytet uznawano utrzymanie dyscypliny budżetowej ${ }^{7}$. Niski dług publiczny i znajdujący się pod kontrolą deficyt budżetowy miał być zasadniczym czynnikiem zapewniającym zewnętrzną oraz wewnętrzną równowagę gospodarczą. Bezpieczny poziom zadłużenia publicznego powinien zapewniać łatwą możliwość rolowania długu, szczególnie części znajdującej się w rękach zagranicznych inwestorów. W rezultacie dyscyplina budżetowa powinna sprzyjać stabilizacji kursu walutowego, który stanowił nominalną kotwicę utrzymującą w ryzach inflację ${ }^{8}$. Zmiany poziomu zadłużenia wyznaczane są przez wysokość deficytu budżetowego. Stabilizacja wysokości długu publicznego zmusza do konstrukcji zbilansowanego budżetu. Perspektywa zbilansowanego budżetu wymagała w większości przypadków sukcesywnego obniżenia deficytu budżetowego9. Instrumentem równoważenia finansów publicznych powinny być wydatki budżetowe, a nie strona dochodowa budżetu. W związku $\mathrm{z}$ tym postulowano ograniczenie wydatków. Po pierwsze, uważano za bezproduktywny system subsydiów kierowanych do poszczególnych gałęzi przemysłu lub określonych grup towarowych (np. subsydiowanie cen energii lub żywności) ${ }^{10}$. Po drugie, za najważniejsze wydatki z państwowej kasy uznawano finansowanie szkolnictwa i ochrony zdrowia. Wydatki budżetowe na te cele uznawano za pomocne w podwyższeniu efektywności kapitału ludzkiego. Po trzecie, państwo powinno finansować infrastrukturę, ponieważ skala tych inwestycji i długi okres zwrotu nakładów powodują nikłe zainteresowanie tymi inwestycjami prywatnego kapitału ${ }^{11}$.

Równowaga wewnętrzna i zewnętrzna osiągnięta dzięki dyscyplinie budżetowej i stabilnemu kursowi otwierała drogę do liberalizacji handlu i przepływów finansowych. Transparentna polityka fiskalna państwa

7 J. Daniel, J. Davis, M. Fouad, C. Rijckghem, Fiscal Adjustment for Stability and Growth, IMF Pamphlet Series nr 55, Washington 2006.

8 Początkowo MFW postulował wprowadzenie sztywnego kursu walutowego, jako kotwicy antyinflacyjnej. Głęboki kryzys bilansu płatniczego w Argentynie spowodował zmianę poglądu i aprobatę bardziej elastycznych systemów kursowych. W przypadku Polski początkowo wprowadzony sztywny kurs walutowy został zastąpiony systemem pływającego kursu (R. Mundell, Do Exchange Rates Work? Another View, IMF Working Paper 1991, nr 37, Washington).

9 W warunkach poważnego zadłużenia konieczne było uzyskanie nadwyżki pierwotnej.

${ }^{10} \mathrm{~J}$. Cordoba i in., Equity and Efficiency in the Reform of Price Subsidies: A Guide for Policymakers, IMF Manuals and Guides, Washington 2000.

${ }^{11}$ S. Gupta, K. Honjo, M. Verhoeven, Transition Economies: How Appropriate Is the Size and Scope of Government?, „Comparative Studies” 2001, t. 45, nr 4, s. 554-557. 
w połączeniu ze swobodną konkurencją powinna spowodować napływ zagranicznych inwestycji bezpośrednich. Proces ten powinien zostać przyspieszony przez prywatyzację istniejących państwowych firm. W rezultacie zastrzyk zewnętrznego kapitału powinien pozwalać na przyspieszenie wzrostu gospodarczego pomimo niskiej skłonności do oszczędzania. Zewnętrzne oszczędności powodowały powstanie deficytu na rachunku bieżącym, ale równowaga zewnętrzna (bilansu płatniczego) była utrzymywana dzięki trwałemu napływowi zagranicznego kapitału ${ }^{12}$.

Stworzenie środowiska konkurencyjnej gospodarki miała zapewnić głęboka deregulacja w kilku wymiarach. Po pierwsze, postulowano swobodną działalność zagranicznych inwestorów w zakresie wyboru kierunków inwestowania, dostępu do ograniczonych czynników produkcji (np. ziemi), swobodną wymianę walutową dochodów i nieskrępowany transfer zysków za granicę. Po drugie, rekomendowano przeciwdziałanie monopolizacji rynku wewnętrznego. Po trzecie, zachęcano do deregulacji rynku pracy (liberalizacja prawa pracy). Po czwarte, postulowano powstrzymanie się od kontroli cen, zniesienie barier importowych i rezygnację z subsydiowania kosztów kredytu. W rezultacie ceny, płace, stopy procentowe powinny być swobodnie kształtowane przez mechanizmy rynkowe ${ }^{13}$.

Opisane cechy systemu gospodarczego powinny zostać zakotwiczone w transparentnym i stabilnym systemie prawa gospodarczego zarówno w aspekcie jego tworzenia, jak i egzekwowania. W tym zakresie najważniejsze było zapewnienie przestrzegania prawa własności ${ }^{14}$.

System podatkowy powinien być całkowicie podporządkowany wyżej opisanemu modelowi gospodarczemu. Po pierwsze, celem systemu podatkowego powinno być dostarczenie dochodów niezbędnych do sfinansowania wydatków budżetowych. System podatkowy powinien być tak skonstruowany, by dostarczał dochodów rosnących proporcjonalnie do wzrostu produktu krajowego brutto (PKB) bez konieczności zmian stawek podatkowych lub wprowadzania nowych form opodatkowania. Spełnienie tego warunku wymagało zaprojektowania podatków z różnych źródeł, tak by wpływy podatkowe były odporne na zmiany koniunktury

${ }^{12}$ G. Calvo, J. Frenkel, From Centrally Planned to Market Economies: The Road from CPE to PCPE, IMF Staff Papers 1991, t. 38, s. 268-299.

13 S. Fischer, A. Gelb, Issues in Socialist Economy Reform, "Journal of Economic Perspective" 1991, t. 5, nr 4, s. 91-105.

14 D. Lipton, J. Sachs, Privatization in Eastern Europe: The Case of Poland, „Brookings Paper of Economic Activity” 1990, t. 2, s. 293-341. 
w poszczególnych branżach. Trwałe powiększenie dochodów podatkowych powinno odbywać się nie poprzez zwiększenie obciążeń podatkowych, ale na drodze powiększenia bazy podatkowej. Po drugie, podatki nie powinny powodować zniekształcenia relacji cenowych. Zróżnicowanie stawek podatkowych na poszczególne towary skutkuje niewłaściwymi sygnałami dla rynku i prowadzi do nieracjonalnej alokacji czynników wytwórczych. Po trzecie, system podatkowy powinien brać pod uwagę proporcje pomiędzy konsumpcją i inwestycjami. Właściwym regulatorem jest stopa procentowa. Podatki nie powinny zakłócać tego mechanizmu. Na przykład wprowadzenie ulg inwestycyjnych może skutkować podejmowaniem nierentownych projektów inwestycyjnych. Po czwarte, system podatkowy powinien być sprawiedliwy, to znaczy równo traktować podmioty gospodarcze funkcjonujące w podobnych warunkach. Uznawano również, że system podatkowy ma ograniczone możliwości przeciwdziałania ubóstwu poprzez wtórną redystrybucję dochodów. Przeciwdziałanie biedzie powinno być realizowane za pomocą innych instrumentów niż system podatkowy. Po piąte, system podatkowy powinien być prosty z małą liczbą stawek podatkowych, pozbawiony ulg, łatwy do zarządzania i przede wszystkim zrozumiały dla podatnika. Po szóste, zmiany systemu podatkowego powinny być rzadkie, kierunek tych zmian sygnalizowany podmiotom gospodarczym. W szczególności potencjalne zmiany wysokości stawek podatkowych nie powinny istotnie zmieniać warunków opłacalności prowadzonej działalności gospodarczej ${ }^{15}$.

Opisana wyżej mantra przyświecała również MFW przy formułowaniu rekomendacji dla krajów transformacji systemowej ${ }^{16}$. Problem polegał na tym, że system rynkowy nie był poprawiany, jak w przypadku krajów Ameryki Południowej, lecz tworzony - zarówno w sensie wprowadzania nowych stosunków własnościowych (prywatyzacja i komercjalizacja przedsiębiorstw państwowych), jak i budowy podstawowych struktur gospodarki rynkowej, w tym nowoczesnego systemu podatkowego.

15 V. Tanzi, Z. Howell, Fiscal Policy and Long-Run Growth, IMF Working Paper 1996, nr 119, Washington.

${ }^{16}$ V. Tanzi, Z. Howell, Tax Policy for Emerging Markets: Developing Countries, IMF Working Paper 2000, nr 35, Washington. 
3. Budowa systemu podatkowego w Polsce W OKRESIE TRANSFORMACJI SYSTEMOWEJ

Tworzenie na początku lat dziewięćdziesiątych nowego systemu podatkowego było procesem wielopłaszczyznowym, obejmującym powstanie odpowiednich instrumentów podatkowych, właściwych ram prawnych, instytucji zdolnych do egzekwowania obowiązku podatkowego oraz harmonizację systemu podatkowego $\mathrm{z}$ mechanizmami funkcjonowania finansów publicznych. Waga problemu była dostrzegana zarówno po stronie władz polskich, jak i MFW, w związku z tym już w 1990 r. zorganizowano dwie misje eksperckie MFW, których celem była analiza możliwości wprowadzenia podatku VAT oraz pomoc w przeorganizowaniu administracji podatkowej. Misje szybko zorientowały się, że głównym czynnikiem powodzenia będzie właściwe przygotowanie aparatu skarbowego, dlatego kontynuowano wysyłanie misji z zadaniem przeglądu prowadzanych reform administracji podatkowej aż do listopada $1992 \mathrm{r}^{17}$

MFW zdawał sobie sprawę, że proces reformowania administracji musi wykorzystywać istniejące zasoby kadrowe i struktury organizacyjne. Uznawano, że najważniejszym przedsięwzięciem powinno być stopniowe poszerzenie funkcji administracji skarbowej, od prostego procesu ewidencjonowania odprowadzanych podatków, przez przedsiębiorstwa państwowe, do pełnego zakresu operacji skarbowych. Nowe zadania wymagały szkolenia kadr i reorganizacji służb podatkowych. Misja miała pełną świadomość, jakim wyzwaniem dla przekształcanego aparatu skarbowego był pobór podatków od gwałtownie rozwijającego się sektora prywatnych przedsiębiorstw. W starym systemie struktura organizacyjna podporządkowana była poborowi podatków od poszczególnych rodzajów podmiotów, w nowym systemie musiała zostać zmieniona w taki sposób, by uwzględniać trzy odrębne etapy: pobór, kontrolę wysokości podatku i rozpatrywanie odwołań podatkowych. Funkcje te powinny spełniać wyodrębnione organizacyjnie struktury. Uporządkowania organizacyjnego wymagał system decyzyjny związany ze sposobem nakładania i egzekwowania kar podatkowych. Baza podatkowa, która zawsze była w centrum uwagi MFW, wymagała zbudowania nowoczesnego systemu rejestracji podatników. Oddzielnym wyzwaniem był proces weryfikowania zwrotu podatków (szczególnie

17 Misje organizowane były przez Fiscal Affairs Department (FAD): w czerwcu 1990 r. misja poświęcona wprowadzeniu podatku VAT, w listopadzie 1990 r. misja z zadaniem zaprojektowania organizacji poboru podatku VAT. 
w odniesieniu do planowanego wprowadzenia systemu podatku VAT). Tempo reform administracji skarbowej, ze względu na ich szeroki zakres, budziło obawy MFW. Wskazywano na opóźnienia w komputeryzacji izb skarbowych i na pracochłonność posługiwania się bazami podatników prowadzonymi na podstawie papierowej dokumentacji. Podkreślano problem przestępstw podatkowych, w związku z czym MFW popierał powołanie służb podatkowych operujących według zasad policyjnych ${ }^{18}$.

Rzeczywisty postęp w zmianie systemu podatkowego najlepiej odzwierciedlało wprowadzenie nowoczesnych podatków dochodowych i podatku nakładanego na towary konsumpcyjne. Sekwencja, w jakiej wprowadzano poszczególne podatki, była wyznaczona zarówno przez konieczność zapewnienia spójności procesu transformacji, jak i skalę niezbędnych dostosowań organizacyjnych.

Wprowadzenie mechanizmu rynkowego wymagało przekształcenia zasad funkcjonowania przedsiębiorstw państwowych. Zasadniczym czynnikiem było wyegzekwowanie twardych ograniczeń budżetowych od przedsiębiorstw państwowych ${ }^{19}$. Misja dokonała analizy opodatkowania przedsiębiorstw państwowych w postaci dywidendy płaconej od posiadanego majątku. System ten, ze względu na wyliczenie wartości majątku na podstawie historycznych cen, nie był odpowiedni w warunkach wysokiej inflacji. Dodatkowo mechanizm ten komplikowało rozdzielenie rozliczenia dywidendy pomiędzy władze lokalne i centralne. Konieczne było wprowadzenie podatku dochodowego, niezbędnego w warunkach równego obowiązku podatkowego dla przedsiębiorstw państwowych i dla firm prywatnych. W rezultacie wprowadzono ujednolicony podatek dochodowy $(\mathrm{CIT})^{20}$. Objęcie przedsiębiorstw powszechnym podatkiem $\mathrm{z}$ ujednoliconą stawką było zgodne z zaleceniem Międzynarodowego Funduszu Walutowego, ponieważ wprowadzało zasady wolnej konkurencji dla przedsiębiorstw $^{21}$. Istotne zróżnicowanie początkowych warunków, w jakich

${ }_{18}$ International Monetary Fund, Republic of Poland, Country Report 92/139, IMF, Washington 1992, s. 31-33.

19 M. Belka, S. Krajewski, B. Pinto, Transforming State Enterprises in Poland: Evidence on Adjustment by Manufacturing Firms, World Bank Working Paper WPS1101, Washington 1993.

20 Podatek dochodowy od osób prawnych, wprowadzony w styczniu 1989 r., został przekształcony nowelizacją z lutego $1992 \mathrm{r}$.

21 L. Ebrill i in., Poland: The Path to a Market Economy, IMF Occasional Paper nr 113, Washington 1994, s. 7-10. 
przyszło gospodarować przedsiębiorstwom, wymusiło wprowadzenie mechanizmów korygujących. Pozostawiono oddzielne systemy podatkowe dla rolnictwa i gospodarki leśnej. Wprowadzono ulgi podatkowe, np. odliczanie kosztów inwestycji. Równolegle zastosowano formy ryczałtowego opodatkowania dla burzliwie rozwijającego się sektora mikroprzedsiębiorstw. Te ustępstwa w stosunku do „wzorcowego” rozwiązania miały długoterminowy, negatywny wpływ na proces alokacji czynników produkcji. Uruchomione zostały mechanizmy przesuwania działalności gospodarczej do obszarów cieszących się ulgami podatkowymi lub uproszczonymi formami opodatkowania. Próby ograniczenia nadużyć podatkowych w tym zakresie prowadziły do rozbudowania systemu sprawozdawczo-kontrolnego służb podatkowych. Ulgi podatkowe, które miały być instrumentem przejściowym, stały się przedmiotem politycznego lobbingu i trudnym do wyeliminowania elementem. $Z$ tego powodu zalecenie usuwania ulg $\mathrm{w}$ podatku dochodowym stało się trwałą rekomendacją międzynarodowych organizacji gospodarczych, w tym MFW ${ }^{22}$.

Wprowadzony w lipcu 1992 r. podatek od dochodów osobistych (PIT) był przedsięwzięciem trudnym do przeprowadzenia pod względem organizacyjnym, szczególnie w sytuacji operowania papierowymi dokumentami. Mimo rad MFW pozostawiono znaczną liczbę ulg podatkowych (łączne rozliczenie podatkowe małżonków, odliczenia wydatków związanych z mieszkaniem, edukacją, ochroną zdrowia) oraz silną progresję podatkową (19, 30 i 40 procent). Fundusz był przeciwny traktowaniu systemu podatkowego jako instrumentu prowadzenia polityki socjalnej. Ograniczenie progresji podatkowej, zdaniem MFW, miało znaczenie ze względu na zakres podatku PIT, który był podatkiem dochodowym nie tylko dla osób uzyskujących dochody z pracy, ale również dla osób samodzielnie prowadzących działalność gospodarczą.

Najbardziej ambitnym przedsięwzięciem było wprowadzenie podatku od towarów i usług (VAT) w styczniu 1993 r. W krajach transformacji systemowej była to rewolucja gospodarcza. Stosowany wcześniej podatek obrotowy z wieloma, często zmienianymi stawkami podatkowymi istotnie wypaczał strukturę cen i był źródłem niewłaściwej alokacji czynników produkcji. Międzynarodowy Fundusz Walutowy zachęcał do wprowadzenia podatku VAT, ponieważ opierał się on na opodatkowaniu konsumpcji i był

${ }^{22}$ International Monetary Fund, Republic of Poland - Selected Issues, Country Report 99/52, IMF, Washington 1997, s. 7-9. 
najbardziej neutralny w stosunku do wyboru kierunku działalności gospodarczej na podstawie rachunku ekonomicznego. Złożony mechanizm rozliczania i poboru podatku wymagał nie tylko sprawnie działającego aparatu skarbowego, ale także właściwych dostosowań organizacyjnych w przedsiębiorstwach. MFW nalegał na wprowadzenie jak najprostszego podatku VAT, to znaczy o możliwie szerokim zakresie towarów obłożonych podatkiem i z zastosowaniem jednej stawki podatkowej po to, by uprościć system rozliczenia podatku, szczególnie zmniejszyć skalę zwrotów podatkowych ${ }^{23}$.

W połowie lat dziewięćdziesiątych sprawy podatkowe, po uruchomieniu podatków CIT, PIT i VAT oraz reorganizacji służb podatkowych, nie były priorytetem dla Międzynarodowego Funduszu Walutowego. Główne zainteresowanie dotyczyło odpowiedzialnej polityki budżetowej i pieniężnej w warunkach gwałtownie przyspieszającego wzrostu gospodarczego. Obawy o zbyt wolny spadek tempa inflacji skłaniał MFW do rekomendowania zarówno rządowi, jak i bankowi centralnemu prowadzenie bardziej restrykcyjnej polityki fiskalnej i pieniężnej ${ }^{24}$. Instrumentem pozwalającym trzymać w ryzach finanse publiczne były wydatki budżetowe. Wydatkami było łatwiej sterować niż strumieniem podatków i dostosowywać do zmian koniunktury. Ten element był szczególnie ważny, ponieważ dochody podatkowe były procykliczne. Stabilizowanie aktywności gospodarczej możliwe było za pomocą elastycznie dostosowujących się antycyklicznych wydatków budżetowych. Ponadto uważano, że budżet może wspierać działania wpływające na długoterminowe tempo wzrostu gospodarczego, np. przez inwestycje infrastrukturalne. Osiągnięcie opisanych celów było możliwe w systemie budżetowym, w którym ograniczone były sztywne wydatki.

Z podanych powodów MFW bardziej interesował się reformą wydatków publicznych, stabilnością długu publicznego i planami obniżenia deficytu budżetowego niż systemem podatkowym. Wewnętrzna równowaga budżetowa, kontrola deficytu na rachunku bieżącym były w centrum uwagi MFW, i to nie tylko w przypadku Polski, ale także pozostałych krajów transformacji systemowej. Podatki z tej perspektywy były ważne ze względu na wielkość wpływów budżetowych. Po dwóch pierwszych latach transformacji, kiedy dochody podatkowe były na niskim poziomie, około $24 \%$ PKB,

${ }^{23}$ Przegląd zaleceń MFW dotyczących podatku VAT prezentuje praca L. Ebrill, M. Keen, J.-P. Bodin, V. Summers, The Modern VAT, IMF, Washington 2001.

24 Rekomendacje MFW: International Monetary Fund, Republic of Poland, Country Report 97/41, IMF, Washington 1997, s. 26-27. 
reformy podatków przyniosły owoce i poziom podatków zbliżył się do 27\% PKB. Zmianie uległa struktura podatków, spadł udział podatków płaconych przez przedsiębiorstwa, z 6\% do 3\% PKB, co było efektem likwidacji podatku od ponadnormatywnego wzrostu wynagrodzeń, który odgrywał ważną rolę jako przejściowy instrument przeciwdziałający spirali płacowo-cenowej. Spadek ten został wyrównany przez zwiększone wpływy z podatku od dochodów osobistych z 6\% do prawie 8\% PKB oraz przez silny wzrost dochodów z $9 \%$ do $12 \%$ PKB z podatków pośrednich po wprowadzeniu VAT i reformie podatku akcyzowego. Zdaniem MFW prawdopodobna była jednak po 1995 r. stagnacja wpływów podatkowych, ich zwiększenie wymagało zatem dalszych działań, przede wszystkim poszerzenia bazy podatkowej i poprawienia ściągalności podatków ${ }^{25}$.

Te uwagi były przyjmowane przez zmieniające się rządy, ale postęp był ograniczony i raczej nie wynikał z braku potencjału organizacyjnego ani z umiejętności analitycznych i legislacyjnych władz. Główną przyczynę dobrze ujął Grzegorz W. Kołodko, mówiąc: „na sali wykładowej, czy też podczas konferencji wystarczy akademicki wywód, by można było mieć rację, w polityce trzeba mieć większość w parlamencie i przede wszystkim poparcie społeczne i polityczne dla reform" ${ }^{26}$. Interesy polityczne, tak jak wszędzie, wyznaczały tempo dostosowań systemu podatkowego. Bolesne reformy podatkowe udało się na ogół realizować, jeśli były warunkiem politycznego sukcesu. Po dynamicznym okresie głównych reform, cieszących się społeczną akceptacją ze względu na likwidację niewydolnego systemu gospodarki centralnie planowanej, kolejną okazją do skutecznego popchnięcia reform podatkowych była konieczna harmonizacja podatków związana z powszechnie popieranym przystąpieniem do Unii Europejskiej.

\section{REFORMY SYSTEMU PODATKOWEGO I PARAPODATKOWEGO} W OKRESIE AKCESJI DO UNII EUROPEJSKIEJ

Zaangażowanie MFW, w pierwszej połowie lat dziewięćdziesiątych wyraźnie skoncentrowane na krajach transformacji systemowej, musiało ulec osłabieniu w związku z falą kryzysów finansowych, które nastąpiły

25 International Monetary Fund, Republic of Poland - Recent Economic Developments, Country Report 97/54, IMF, Washington 1997, s. 41-43.

${ }^{26}$ G.W. Kołodko, Equity Issues in Policy Making in Transition Economics, [w:] Economic Policy and Equity, red. V. Tanzi, IMF, Washington 1999, s. 150. 
w innych krajach wschodzącego rynku. Początkiem problemów było załamanie meksykańskiego peso w grudniu 1994 r., które wywołało efekt domina oraz wyprzedaż brazylijskiej i argentyńskiej waluty (tzw. tequila kryzys) ${ }^{27}$. W kolejnych latach kryzys dotknął kraje Dalekiego Wschodu (1997). Szybki wzrost gospodarczy tych krajów, napędzany przez napływ zagranicznego kapitału, załamał się na skutek kryzysów walutowych. System sztywnego kursu walutowego, który stanowił kotwicę antyinflacyjną, nie był możliwy do utrzymania $\mathrm{w}$ tych krajach w warunkach raptownego odpływu zagranicznego finansowania. Bilans płatniczy musiał być łatany przez pożyczki zaciągane w MFW. Programy stabilizacyjne były jednak okupione bolesnymi społecznie reformami finansów publicznych ${ }^{28}$. Impuls azjatyckiego kryzysu finansowego dotarł również do Rosji i rozpoczął się atakiem spekulacyjnym na rubla. MFW widział możliwość rozprzestrzenienia się kryzysu na kraje Europy Centralnej ${ }^{29}$.

W zaistniałej sytuacji MFW skupił uwagę na czynnikach powodujących napięcia w polskim bilansie płatniczym, które mogły stać się w zarzewiem kryzysu finansowego ${ }^{30}$. Ewolucja systemu kursowego w Polsce od sztywnego kursu, poprzez kurs pełzający, wyraźnie zmierzała do kursu płynnego, dlatego system kursowy nie był przesłanką potencjalnego kryzysu ${ }^{31}$. MFW skupił zatem uwagę na czynnikach pośrednio wpływających na równowagę zewnętrzną, to znaczy na stabilności finansów publicznych i trwałości napływu bezpośrednich inwestycji zagranicznych ${ }^{32}$. W tym pierwszym przypadku MFW sygnalizował potrzebę trwałego ograniczenia deficytu budżetowego, w tym zwrócenia uwagi na przyszły stan finansów publicznych determinowany przez państwowy system emerytalny. W tym drugim zaś przedmiotem troski była właściwa polityka zmierzająca do stworzenia trwałych

27 J. Boughton, From Suez to Tequila: The IMF as Crisis Manager, IMF Working Paper 1997, nr 90, Washington.

${ }_{28}$ M. Musa, M. Savastano, The IMF Approach to Economic Stabilization, IMF Working Paper 1999, nr 104, Washington.

${ }^{29}$ International Monetary Fund, Financial Crises: Characteristics and Indicators Vulnerabilities, World Economic Outlook, IMF, Washington 1998, s. 74-97.

30 International Monetary Fund, Republic of Poland, Country Report 98/53, IMF, Washington 1998, s. 6-11.

31 International Monetary Fund, Republic of Poland, Country Report 98/53, IMF, Washington 1998, s. 21-22.

32 International Monetary Fund, Republic of Poland - Selected Issues, Country Report 99/52, IMF, Washington 1997, s. 12-48. 
i stabilnych warunków prowadzenia działalności gospodarczej, szczególnie w odniesieniu do inwestorów zagranicznych.

Rekomendacje MFW były zbieżne z priorytetami polskiego rządu. Cztery reformy rządu Jerzego Buzka (oświatowa, emerytalna, administracji i służby zdrowia) miały w długim okresie stabilizować finanse publiczne i w tym zakresie były zgodne z oczekiwaniami MFW ${ }^{33}$. Najważniejszym czynnikiem było jednak rozpoczęcie procesu akcesyjnego. Po pierwsze, MFW uważał, że konieczność spełnienia warunków Paktu stabilności i wzrostu będzie popychać Polskę do wprowadzenia strukturalnych reform finansów publicznych. Po drugie, harmonizacja prawa, zwłaszcza prawa gospodarczego, powinna istotnie zmniejszyć ryzyko inwestowania w Polsce przez kapitał zagraniczny i tym samym zapewnić trwały napływ inwestycji zagranicznych. $Z$ tego punktu widzenia aparat podatkowy miał być bardziej przyjazny dla biznesu.

W związku z akcesją MFW dokonał przeglądu niezbędnych zmian systemu podatkowego ${ }^{34}$. Z punktu widzenia dochodów ważne było przystąpienie do strefy wspólnego handlu. Ze względu na kierunki polskiego handlu zagranicznego brak ceł w handlu wewnątrzwspólnotowym miał istotne znaczenie dla dochodów budżetowych. Samo wypowiedzenie umów handlowych z poszczególnymi krajami i przystąpienie do wspólnej, europejskiej umowy handlowej było rozbudowanym przedsięwzięciem organizacyjnym, chociaż po przystąpieniu Polski do Światowej Organizacji Handlu dostosowanie systemu taryf celnych nie było skomplikowaną operacją. MFW dostrzegał również istotne znaczenie harmonizacji stawek podatków akcyzowych (paliwo, papierosy) dla wpływów budżetowych. Kwestią otwartą było wynegocjowanie okresów przejściowych pozwalających na stopniowe dostosowanie stawek bez gwałtownych zmian dochodów budżetowych. Ostatnie z podkreślanych przez MFW zadań dotyczyło dostosowania podatku VAT do Szóstej Dyrektywy Unii Europejskiej, co uznawano za poważne wyzwanie w świetle wciąż niedoskonale działającej administracji skarbowej.

Biorąc pod uwagę przyszłe funkcjonowanie Polski w strukturach Unii Europejskiej, władze uważały przeprowadzenie reform podatkowych za niezbędne dla stopniowego zwiększania konkurencyjności polskiej gospodarki.

33 International Monetary Fund, Republic of Poland, Country Report 98/53, IMF, Washington 2004, s. 23-25.

34 International Monetary Fund, Republic of Poland - Selected Issues and Statistical Appendix, Country Report 98/62, IMF, Washington 1992, s. 6-7. 
Pod koniec 1998 r. dwie misje MFW uczestniczyły w oszacowaniu skutków dla dochodów podatkowych przygotowywanej reformy podatków dochodowych. Plany rządowe przedstawione zostały w Białej księdze podatków $w^{35}$. Ideą przewodnią reformy było obniżenie stawek podatkowych i równoczesne zlikwidowanie ulg i zwolnień podatkowych. W rezultacie cała operacja powinna być neutralna pod względem wpływów podatkowych, pod warunkiem wprowadzenia planowanych zmian w podatkach pośrednich, narzuconych przez proces unijnej harmonizacji.

W odniesieniu do podatku CIT proponowano rozwiązania już wcześniej sygnalizowane przez MFW, likwidację stosowanych ulg, przede wszystkim wyeliminowanie skomplikowanej w nadzorowaniu ulgi inwestycyjnej i zastąpienie jej mechanizmem przyspieszonej amortyzacji. Zmiana ta miała być połączona z procesem regularnego przeszacowania wartości majątku przedsiębiorstw. Zdecydowano się także na postulowaną przez MFW likwidację ulg związanych z zatrudnieniem osób niepełnosprawnych. Równolegle miała być stopniowo obniżana stawka podatku dochodowego z obowiązującego poziomu 34\% w 1999 r. do poziomu 22\% w 2004 r.

Propozycje zmiany podatku PIT poprzedziła intensywna dyskusja na temat możliwości wprowadzenia podatku liniowego w Polsce. MFW sprzyjał tej idei z trzech powodów. Po pierwsze, progresja podatkowa, w przypadku dużego zróżnicowania dochodów, w porównaniu z podatkiem liniowym prowadzi do wysokich krańcowych stawek podatkowych, jeśli wpływy podatkowe mają zostać na tym samym poziomie. Po drugie, niwelowanie społecznych różnic należy realizować za pomocą innych instrumentów niż system podatku dochodowego. Po trzecie, wprowadzenie podatku liniowego pozwala na pobór podatku „u źródła”, co znacznie upraszcza zarządzanie systemem podatkowym. Kolejne misje MFW w 1999 r. wspierały przygotowania do reformy. Koncepcja podatku liniowego miała sens, jeśli reforma nie ograniczała się do wprowadzenia jednej stawki podatkowej, ale ponadto zakładała eliminację ulg, w tym możliwość wspólnego, podatkowego rozliczania się małżonków. Ze względów społecznych tak daleko idący projekt nie uzyskał poparcia i został zawetowany przez prezydenta.

Połowiczna reforma podatków dochodowych spotkała się ze zróżnicowaną oceną MFW. Z jednej strony podkreślano, że reforma jest ważnym sygnałem woli władz dla stworzenia lepszych warunków działalności gospodarczej

${ }_{35}$ Ministerstwo Finansów, Biała księga podatków. Analiza obecnego systemu podatkowego. Propozycje zmian, Warszawa 1998. 
dla przedsiębiorców zarówno krajowych, jak i zagranicznych. Wskazywano też, że wprowadzone ustawy skutkują pozytywną zmianą struktury dochodów podatkowych. Udział we wpływach podatkowych podatków dochodowych, wynoszący przed reformą około $40 \%$, miał spaść prawie o połowę. Z drugiej strony pokazywano niespójności wprowadzonych rozwiązań. Po pierwsze, różne stawki opodatkowania i odmienny sposób liczenia podstawy opodatkowania dla przedsiębiorców rozliczających się w systemie CIT, i tych, którzy byli opodatkowani PIT, nie stwarzał tych samych warunków gospodarowania. MFW uważał, że lepszym rozwiązaniem było wprowadzenie ujednoliconych przepisów o podatku dochodowym zarówno dla osób fizycznych, jak i biznesu, z jednolitą stawką podatkową. Po drugie, podkreślano wyłączenie $\mathrm{z}$ systemu podatków dochodowych pewnych sektorów (rolnictwo, specjalne strefy ekonomiczne) i dochodów (oprocentowanie rachunków bankowych i zyski kapitałowe z inwestycji w papiery wartościowe). Po trzecie, wskazywano na ubytki w dochodach samorządów związane $\mathrm{z}$ reformą i postulowano wprowadzenie mechanizmów kompensacyjnych ${ }^{36}$.

Najważniejszym sygnałem problemów, jakie przyniesie połowiczna reforma, była analiza skali spadku dochodów podatkowych PIT i CIT. Udział dochodów z tych podatków miał się obniżyć z około 9\% do około 6\% PKB. Konieczne było zatem przyspieszenie wzrostu stawek podatku akcyzowego przewidywanego w procesie harmonizacji z systemem unijnym. Również dostosowanie do wymogów Szóstej Dyrektywy powinno zakładać objęcie stawką podstawową VAT jak największej liczby towarów i usług. MFW proroczo podkreślał, że ambitny cel, jakim było zrównoważenie budżetu w 2003 r., jest zagrożony. Poprawa salda finansów publicznych o ponad 3\% w ciągu czterech lat, uwzględniając prognozę wpływów podatkowych, musiała wymagać istotnego ograniczenia wydatków publicznych.

Połowiczna reforma podatkowa pozostawiła trwały ślad w kolejnych opiniach MFW, który niezmiennie domagał się likwidacji ulg podatkowych, prostszego prawa podatkowego i efektywniejszego funkcjonowania aparatu skarbowego. Niestety rady MFW traktowano wybiórczo, publiczną sympatią cieszyły się postulaty uproszczenia procedur podatkowych oraz obniżenia stawek podatkowych, ale zapominano, że MFW widział taką możliwość pod warunkiem poszerzania bazy podatkowej lub ograniczenia sztywnych wydatków.

${ }^{36}$ International Monetary Fund, Republic of Poland - Selected Issues, Country Report 00/46, IMF, Washington 2000, s. 19-29. 
Część postulatów MFW wprowadzono w późniejszym czasie, opodatkowano dochody z oprocentowania rachunków bankowych, zyski kapitałowe $\mathrm{z}$ inwestycji w papiery wartościowe, zmniejszono liczbę ulg w podatku PIT, lecz nie wprowadzono jednolitego podatku dochodowego ani tej samej stawki podatkowej dla wszystkich podatków dochodowych (pomimo podjęcia prób w tym zakresie). Wprowadzono natomiast namiastkę podatku liniowego, to znaczy opcję tego podatku dla osób prowadzących działalność gospodarczą i rozliczających się w systemie PIT. Uzupełniono lukę w ustawodawstwie i uchwalono ustawę o dochodach jednostek samorządu terytorialnego wprowadzającą, postulowany przez MFW, mechanizm regulujący udział władz lokalnych w podatku dochodowym ${ }^{37}$.

Z czterech planowanych w 1998 r. reform strukturalnych MFW najbardziej zaangażował się w reformę emerytalną. Państwowy system emerytalny $\mathrm{z}$ obowiązkowym systemem składkowym był w rzeczywistości systemem parapodatkowym. MFW interesował się tym rozwiązaniem w krajach transformacji systemowej z dwóch powodów. Po pierwsze, niewydolny system emerytalny musiał być dofinansowywany z budżetu i mógł być główną przyczyną wysokiego deficytu, zwłaszcza biorąc pod uwagę perspektywę negatywnych zmian demograficznych. Po drugie, składka emerytalna działa jak parapodatek i wpływa na koszt czynnika produkcji, jakim jest praca ${ }^{38}$.

MFW stał na stanowisku, że opodatkowanie konsumpcji jest najmniej zniekształcającym rachunek ekonomiczny rozwiązaniem, podatki nakładane na czynniki produkcji wpływają zaś na ich cenę i ich nadmierne opodatkowanie może hamować wzrost gospodarczy ${ }^{39}$. W związku z tym czynniki produkcji powinny podlegać umiarkowanemu opodatkowaniu. Niskie stopy podatkowe nie wyczerpują listy problemów. Silne zróżnicowanie obciążeń podatkowych poszczególnych czynników powoduje zniekształcenie struktury cen tych czynników. W rezultacie struktura alokacji czynników produkcji może nie być efektywna. W przypadku krajów transformacji systemowej, które doświadczyły wysokiego bezrobocia, problem właściwej relacji opodatkowania kapitału i pracy miał bardzo istotne znaczenie. Ten

37 Najbardziej spójnym planem uporządkowania finansów publicznych, w tym podatków, był tzw. plan Hausnera, który uzyskał silne poparcie MFW, zob. International Monetary Fund, Republic of Poland, Country Report 04/217, IMF, Washington 2004, s. 19.

${ }_{38}$ M. Cangiano, C. Cottareli, L. Cubeddu, Pension Developments and Reforms in Transitional Economies, IMF Working Paper 1998, nr 151, Washington.

39 J. Norregaard, T. Khan, Tax Policy: Recent Trends and Coming Challenges, IMF Working Paper 2007, nr 274, Washington, s. 12-14. 
aspekt w przypadku Polski był szczególnie podkreślany przez MFW. Wysokość podatku od dochodów osobistych i dodatkowych danin związanych z finansowaniem emerytur i systemu ochrony zmuszała do postawienia pytania, czy podatkowe narzuty na koszty pracy nie wpływają na skalę bezrobocia w Polsce. Problem klina podatkowego stał się trwałym elementem raportów MFW w sprawie Polski ${ }^{40}$.

Obniżona stawka podatku PIT, wysoka kwota wolna od podatku, sukcesywne podwyższanie progów podatkowych i wprowadzenie opcji podatku liniowego istotnie ograniczały wpływ podatku dochodowego na klin podatkowy. Czynnikiem zasadniczym dla zmniejszenia klina podatkowego były zmiany systemu emerytalnego. Wprowadzona reforma systemu emerytalnego dzieliła składkę na dwie równe części, płacone przez pracownika i pracodawcę. Dla osób samozatrudnionych, ze względu na skokowy wzrost całkowitej składki, pozwolono na odstępstwo od tej zasady, wprowadzając niezależną od dochodu minimalną, ryczałtową składkę. Zmniejszony w ten sposób klin podatkowy miał jednak negatywne skutki, zachęcał do szerokiego wykorzystania samozatrudnienia, jako alternatywy dla zatrudnienia opartego na umowie o pracę. Takie rozwiązanie wpływało negatywnie na strumień składek zasilających państwowy system emerytalny. W opinii MFW skuteczne zmniejszenie klina podatkowego wiązano z reformą emerytalną, w której znaczna część emerytury pochodziłaby z dobrowolnego planu emerytalnego, a nie z państwowego systemu opartego na obligatoryjnej składce ${ }^{41}$. MFW promował stopniową budowę takiego systemu i dlatego popierał polski projekt reformy emerytalnej.

MFW i polskie władze były zgodne, że widoczny proces starzenia się polskiego społeczeństwa zmusi do stopniowego obniżenia wskaźnika zastąpienia (relacji emerytury do ostatniego wynagrodzenia) lub spowoduje olbrzymi wzrost składek emerytalnych w przyszłości. Spowodowany tym wzrost klina podatkowego, w warunkach stopniowej konwergencji płac po przystąpieniu do Unii Europejskiej, spowoduje spadek konkurencyjności polskiej gospodarki. MFW zdawał sobie sprawę, że w przypadku krajów transformacji systemowej nie będzie możliwe całkowite odejście od państwowego systemu emerytalnego. W związku $\mathrm{z}$ tym popierano wprowadzenie przez polskie władze rozwiązania wielofilarowego, w którym obok

${ }^{40}$ International Monetary Fund, Republic of Poland - Selected Issues, Country Report 00/46, IMF, Washington 2000, s. 83-86.

${ }^{41}$ International Monetary Fund, Republic of Poland - Selected Issues, Country Report 00/46, IMF, Washington 2000, s. 100-101. 
sektora publicznego emerytury wypłacane byłyby z oszczędności w quasi-prywatnych funduszach emerytalnych. Odejście od systemu zdefiniowanej emerytury na rzecz systemu zdefiniowanej składki miało zapobiec przyszłemu kryzysowi systemu emerytalnego. Uzależnienie emerytury od sumy uzbieranych składek miało skłonić ludzi do pracy w dłuższym okresie, niż wynikałoby to $\mathrm{z}$ obecnego wieku emerytalnego. W rezultacie skrócony zostałby średni okres przebywania na emeryturze i w ten sposób uniknięto by drastycznego obniżenia stopy zastąpienia ${ }^{42}$.

Wprowadzenie systemu wielofilarowego, w tym uruchomienie prywatnych funduszy emerytalnych, przeprowadzono sprawnie. MFW wskazywał, że głównym czynnikiem powodzenia reformy jest mechanizm pokrywania kosztów nowego systemu w okresie przejściowym funkcjonowania starego systemu, zwanego pay-as-you-go. Składki osób zakwalifikowanych do nowego systemu częściowo były transferowane do otwartych funduszy emerytalnych, które miały wypłacać część emerytury dopiero w przyszłości. W związku z tym powstała emerytalna luka finansowa pomiędzy wartością wypłacanych na bieżąco emerytur a sumą składek emerytalnych pomniejszonych o kwotę transferu do otwartych funduszy emerytalnych. Ten koszt wprowadzenia reformy emerytalnej musiał być pokrywany ze środków budżetowych. MFW proponował kilka działań, które mogły zmniejszyć obciążenia fiskalne przez reformę. Po pierwsze, wskazywano na wpływy z prywatyzacji majątku państwowego. Po drugie, zachęcano do objęcia reformą grup pracowniczych mających własne, państwowe systemy emerytalne i likwidację przywilejów emerytalnych. Po trzecie, uznawano za niezbędną reformę KRUS i zmniejszenie obciążeń budżetowych związanych z emeryturami rolniczymi. Po czwarte, nakłaniano do wydłużenia ustawowego wieku przejścia na emeryturę i zrównania pod tym względem praw mężczyzn i kobiet $^{43}$. Rzeczywistość poddała krytycznemu testowi zalecenia MFW ${ }^{44}$. Kolejne rządy wprowadzały reformy, inne się z nich wycofywały. Dobrym przykładem są zmiany wieku emerytalnego, indeksacja tylko inflacją środków

${ }^{42}$ International Monetary Fund, Republic of Poland - Selected Issues, Country Report 00/60, IMF, Washington 2000, s. 43-44.

${ }^{43}$ International Monetary Fund, Republic of Poland, Country Report 04/217, IMF, Washington 2004, s. 11-13.

${ }^{44}$ Kompleksową ocenę MFW reform emerytalnych wprowadzonych na tle innych krajów Europy Centralnej zawiera praca: International Monetary Fund, The EU Fiscal Framework and Pension Reform, [w:] Central and Eastern Europe, New Member State Policy Forum, Country Report 15/98, IMF, Washington 2015, s. 64-77. 
gromadzonych w pierwszym filarze emerytalnym, próby uszczelnienia systemu KRUS czy eliminacja branżowych przywilejów emerytalnych.

Bezpośrednim czynnikiem, który przesądził o demontażu zreformowanego system, był sposób inwestowania środków przez otwarte fundusze emerytalne. Podaż instrumentów finansowych, jakie mogły nabywać fundusze emerytalne, była ograniczona. W grę wchodziły papiery wartościowe dopuszczone do obrotu publicznego (akcje i obligacje). Ograniczone były możliwości inwestowania $\mathrm{w}$ zagraniczne instrumenty finansowe, $\mathrm{w}$ rezultacie znaczna część środków transferowanych do funduszy emerytalnych inwestowana była $\mathrm{w}$ obligacje skarbowe. Tym samym wypaczona została idea reformy emerytalnej, miała ona bowiem ograniczyć przyszłe zobowiązania finansów publicznych związane z procesem starzenia się społeczeństwa. Skutki reformy spowodowały, że znaczna część tego zadłużenia związana z emerytalną luką finansową nie znikła, tylko przyjęła formę obligacji Skarbu Państwa znajdujących się w rękach funduszy emerytalnych ${ }^{45}$.

Połowicznie wprowadzona reforma stała się istotnym bieżącym obciążeniem finansów publicznych, którego wprowadzający reformę nie przewidzieli. MFW był sceptyczny w odniesieniu do początkowych szacunków kosztów emerytalnej luki finansowej prezentowanych przez rząd ${ }^{46}$ i z tego powodu sugerował kolejne niezbędne działania. Dodatkowym czynnikiem utrudniającym sytuację było stanowisko Komisji Europejskiej, która tylko część kosztów reformy emerytalnej pozwalała przejściowo odejmować od deficytu sektora przy wyliczaniu kryteriów z Maastricht ${ }^{47}$.

\section{Kierunek Zaleceń Mį̨dzynarodowego Funduszu Walutowego po WejŚciu Polski do UniI EURopejskiej}

Proces harmonizacji systemu podatkowego z systemem wspólnotowym przebiegł sprawnie. Realizacja wymagań stawianych krajom członkowskim, szczególnie w zakresie ulg podatkowych deformujących warunki

${ }^{45}$ MFW dostrzegał przyczyny głębokich zmian, podkreślał potrzebę utrzymania zdefiniowanej składki w pierwszym filarze systemu emerytalnego, zob. International Monetary Fund, Republic of Poland, Country Report 14/173, IMF, Washington 2014, s. 16.

46 Pełną ocenę kosztów reformy emerytalnej MFW oficjalnie przedstawił w okresie, gdy rozpoczęto odwrót od reformy, zob. International Monetary Fund, Republic of Poland - Selected Issues, Country Report 11/167, IMF, Washington 2011, s. 11-13.

47 Ministerstwo Finansów, Odpowiedź na interpelacje poselska 19430/2010 w sprawie możliwości odliczania kosztów reformy emerytalnej od długu publicznego, Warszawa 2010. 
konkurencji, została przeprowadzona szerzej niż w krajach już należących do Unii. W odniesieniu do podatku VAT znalazło to wyraz w mniejszej liczbie towarów uprawnionych do niższych niż podstawowa stawek podatkowych. Aparat skarbowy i celny w wystarczający sposób wdrożył reguły postępowania, pozwalając przedsiębiorstwom rozliczać podatki według wspólnych, unijnych zasad na wspólnym unijnym rynku ${ }^{48}$.

Sytuacja uległa istotnej zmianie po kryzysie finansowym. W latach 2008 i 2009 wpływy z podatków VAT i CIT w „starych” krajach Unii Europejskiej spadły w porównywalnym stopniu jak w środkowoeuropejskich krajach UE. Było to efektem spadku aktywności gospodarczej, co zmniejszało bazę podatkową. Równolegle rządy uruchamiały pakiety pomocowe dla przedsiębiorstw i upraszczały procedury podatkowe. W 2009 r. dochody z VAT w środkowoeuropejskich krajach powróciły do poziomu przedkryzysowego. Natomiast w tym samym roku wpływy z tego podatku w Polsce spadały, co więcej, procesu względnego spadku nie udało się zahamować w kolejnych latach mimo podwyżki podstawowej stawki podatkowej VAT. W 2011 r. dochody z podatku VAT mierzone jako procent PKB były o półtora punktu niższe niż w przedkryzysowym roku 2007. W podanym okresie nastąpił również spadek dochodów CIT o prawie punkt procentowy PKB. Była to znaczna zmiana ze względu na niski udział tego podatku w dochodach. Wpływy z podatku CIT silniej reagują na spadek koniunktury. Spadek dochodów budżetowych z CIT może trwać dłużej ze względu na możliwość uwzględnienia straty w rozliczeniu podatkowym w kolejnych latach.

Trwałość zaobserwowanych trendów skłaniała do wszechstronnego przeglądu funkcjonowania administracji podatkowej, ustalenia przyczyn niższej efektywności podatkowej i opracowania programu naprawczego. Ministerstwo Finansów zwróciło się do MFW o przysłanie misji, której celem była pomoc w rozwiązaniu problemu. Na podstawie prac misji w 2014 r. powstał raport zawierający diagnozę sytuacji i rekomendacje stosownych działan $^{49}$.

Misja uwagę skoncentrowała na dwóch niepokojących zjawiskach: rosnącym długu w postaci zaległości podatkowych i gwałtownym wzroście zwrotów podatkowych. Akumulacja zadłużenia wskazywała na małą

48 International Monetary Fund, Republic of Poland, Country Report 06/391, IMF, Washington 2006, s. 11-12.

${ }^{49}$ International Monetary Fund, Technical Assistance Report - Tax Administration Challenges and Strategic Priorities, Country Report 15/112, IMF, Washington 2015. 
wydolność działań windykacyjnych. Wzrost zwrotów podatkowych sygnalizował powstanie mechanizmów wyłudzenia środków z systemu podatkowego. Skala obydwu procesów i przegląd funkcjonowania administracji podatkowej skłonił MFW do rekomendowania budowy nowej strategii administracji podatkowej ${ }^{50}$.

Strategia powinna określić docelowy model aparatu skarbowego w postaci zintegrowanej instytucji krajowej administracji podatkowej zajmującej się wszystkimi sprawami podatkowymi (od rozwiązań prawnych, poprzez procedury poboru i audytu podatkowego, kończąc na technice gromadzenia i analizy informacji podatkowej). Według MFW skala pożądanych zmian była na tyle duża, że plan zmian powinien obejmować okres pięcioletni. Efektywne wdrożenie strategii wymagało wyznaczenia osoby odpowiedzialnej za cały proces, o szerokich kompetencjach i wspieranej przez komitet o silnej pozycji w hierarchii rządowej. Wieloetapowy proces reformy, realizowany w warunkach prowadzenia normalnej działalności systemu podatkowego, wymagał, zdaniem MFW, takich rozwiązań, by proces reform nie był spychany na dalszy plan. Konieczna integracja spraw podatkowych $\mathrm{w}$ jednej instytucji odpowiedzialnej za sprawy podatkowe wymagała przebudowy struktury departamentów funkcjonujących w Ministerstwie Finansów ${ }^{51}$.

MFW postulował zmiany proporcji zatrudnienia, szczególnie zwiększenie liczby pracowników zajmujących się audytem i analizą ryzyka, do poziomu jednej czwartej ogółu zatrudnionych. Za zmianą ilościową zatrudnienia powinny iść zmiany jakościowe, to znaczy stworzenie kadr zdolnych do przeprowadzenia nowoczesnej analizy ryzyka (Compliance Risk Model). Dominująca rola w systemie podatkowym centrali wymagała struktury, w której centrala zatrudnia co najmniej 5\% ogólnej liczby pracujących w systemie podatkowym. Uważano, że należy skonsolidować regionalne struktury poprzez zmniejszenie liczby małych urzędów skarbowych. MFW postulował również ograniczenie działalności administracji podatkowej tylko do danin powszechnie obowiązujących i mających charakter podatkowy ${ }^{52}$.

Zmiana proporcji kadrowych wymagała pełnej informatyzacji systemu podatkowego, w szczególności integracji rozproszonych baz informacyjnych. Powinna powstać jedna duża baza zawierająca systematycznie

${ }^{50}$ Ibidem, s. 9-11, 20-24.

51 Ibidem, s. 13-16.

52 Ibidem, s. 40-42. 
zbierane informacje o płaconych podatkach i zwrotach podatkowych. Postęp w zarządzaniu administracją podatkową, zdaniem MFW, wymagał przedefiniowania zadań stojących przed poszczególnymi ogniwami systemu i jasnego zdefiniowania zakresu odpowiedzialności. Dla poszczególnych jednostek organizacyjnych systemu powinny być wprowadzone mierniki efektywności realizowanych zadań. Przeglądowi powinien zostać poddany system raportowania, tak by oddzielne analizy dochodów podatkowych można było zintegrować w jeden koherentny raport ${ }^{53}$.

Przeorganizowana struktura administracji podatkowej w odniesieniu do najbardziej palącego zadania, tj. zmniejszenia luki podatkowej VAT, w opinii MFW powinna skupić się na kilku czynnikach. Po pierwsze, powinny zostać wyodrębnione gałęzie działalności gospodarczej najbardziej podatne na oszustwa podatkowe, dla gałęzi tych powinny zostać opracowane właściwe mechanizmy poboru podatku. Po drugie, powinien powstać system szacowania dochodów i oceny ryzyka podatkowego dla szarej strefy. Po trzecie, firmy płacące najwyższe kwoty podatków powinny być obsługiwane przez wyspecjalizowane urzędy podatkowe. Po czwarte, konieczne jest powołanie zintegrowanych służb, które tworzyłyby biuro informacyjne dla podatnika, szczególnie dla mikroprzedsiębiorstw i osób rozpoczynających działalność gospodarczą. Po piąte, system rejestracji podatników VAT powinien zawierać procedury weryfikujące rejestrujący się podmiot ${ }^{54}$.

Przedstawione wyżej rekomendacje MFW dobrze odzwierciedlają postępowanie tej organizacji. Z jednej strony opiera się ona na szerokiej wie$\mathrm{dzy}^{55}$ dotyczącej różnych systemów podatkowych, przeprowadzonych refom i ich skutków. Na tej podstawie jest w stanie zbudować mechanizmy oceny działań, które prowadzą do wyższej efektywności systemu. Z drugiej strony ściśle współpracuje $\mathrm{z}$ rządem, starając się sformułować zalecenia, które są zgodne z priorytetami władz. Rekomendacje z raportu zostały wykorzystane przez polskie władze dwukrotnie.

Pierwszy raz przy powstaniu ustawy o administracji podatkowej z lipca 2015 r. Ustawa ta, zgodnie z zaleceniami MFW, powoływała szefa

53 Ibidem, s. 45-48.

${ }^{54}$ Ibidem, s. 1-3.

${ }^{55}$ Dobrym przykładem wiedzy podatkowej zgromadzonej przez Fiscal Affairs Department MFW jest przegląd systemów zwrotów podatku VAT i proponowanych przez MFW działań w ramach ponad dwudziestoletniej współpracy z krajami wschodzącego rynku, w tym z krajami transformacji systemowej (G. Harrison, R. Krelove, VAT Refunds: A Review of Country Experience, IMF Working Paper 2005, nr 218, Washington). 
administracji podatkowej, który odpowiadał za całokształt spraw podatkowych. Przewidywała również podniesienie jakości obsługi administracji podatkowej. W specjalnie powołanych centrach obsługi podatnika mieli funkcjonować asystenci podatkowi. Powołano też Biuro Krajowej Informacji podatkowej, które miało zarządzać indywidualnymi interpretacjami podatkowymi. Ponadto wprowadzono Centralny Rejestr Danych Podatkowych, narzędzie informatyczne postulowane w raporcie. Ustawa zawierała także rozwiązania, których MFW nie polecał, np. pobór przez administrację podatkową niepodatkowych należności budżetowych.

Drugi raz wpływu rekomendacji MFW można się doszukać w ustawie z 2016 r. wprowadzającej Krajową Administrację Skarbową. Nowa ustawa przede wszystkim inkorporowała służby celne do systemu administracji podatkowej, stawiając przed nimi inaczej zdefiniowane zadania. Niemniej projektodawcy ustawy wychodzili z przesłanek zbliżonych do tych, które sygnalizował raport MFW. Dostrzegano rozproszenie podmiotów zajmujących się sprawami podatkowymi, podkreślano brak jednolitego kierownictwa służb skarbowych. Widziano powielanie tych samych zadań przez różne ogniwa struktury, różne mechanizmy ich kontroli i oceny. Uznawano to za przyczynę nieefektywnego zarządzania zasobami kadrowymi. Ponadto podkreślano braki systemu informatycznego i zgadzano się z opinią MFW, że należy stworzyć zintegrowaną bazę podatkową. Kumulacja złych strukturalnych rozwiązań była powodem niskiej skuteczności w egzekwowaniu zaległych należności podatkowych i narastaniu problemu luki w przypadku podatku VAT.

Misja podatkowa z 2014 r. jest dobrym przykładem tego, jak władze spożytkowują uwagi i propozycje MFW. Model nakreślony przez misję nie jest na ogół całkowicie implementowany, ponieważ MFW wysoko stawia poprzeczkę władzom krajowym. Nawet rozwodnione reformy lub wdrażane etapami zmiany mają jednak pozytywny efekt, jeśli tylko wprowadzone są podstawowe zalecenia MFW, tworzące dla reformy wystarczającą masę krytyczną.

\section{Podsumowanie}

MFW odgrywał niezaprzeczalnie istotną rolę w procesie transformacji. Polska jest przedstawiana jako kraj, który nie tylko odniósł sukces, ale również potrafił nawiązać dialog z MFW i następnie umiejętnie skorzystać $\mathrm{z}$ jego wiedzy i informacji. Reforma podatkowa była częścią całego pakietu 
zmian dokonanych w procesie transformacji, zgodnie ze wzorcem konsensusu waszyngtońskiego. Członkostwo Polski w Unii Europejskiej osłabiło aktywność MFW i z roli inicjatora reform przekształcił się on $\mathrm{w}$ obserwatora i recenzenta zachodzących zmian. Światowe problemy gospodarcze zmuszają jednak do rozważenia nowych obszarów aktywności polityki podatkowej.

Po pierwsze, ostatni kryzys finansowy i narastające nierówności społeczne skłaniają do ponownego rozważenia podatków jako instrumentu korygującego. Stanowisko MFW od zawsze akcentowało nierównowage makroekonomiczną jako główny czynnik sprawczy nierówności społecznych i uczyniło z podatku inflacyjnego symbol antyegalitarnej polityki gospodarczej. Niska inflacja, stabilne kursy walutowe, wolny handel, inwestycje rządu w infrastrukturę społeczną i gospodarczą oraz precyzyjnie kierowane programy społeczne miały wystarczać dla przeciwdziałania ubóstwu i nierównościom społecznym. Niskie i powszechne podatki dochodowe sprzyjają takiemu programowi gospodarczemu. Fala społecznego egalitaryzmu, napięte budżety skłaniają rządy do aktywnej polityki podatkowej odbiegającej od zaleceń MFW. W Polsce świadczą o tym specjalne podatki nakładane na wybrane sektory gospodarcze.

Po drugie, globalizacja popierana przez MFW, jako proces zwiększający efektywność i zmniejszający dysproporcje gospodarcze pomiędzy krajami, wymagała niskich taryf celnych i liberalnego systemu podatkowego wobec zagranicznych inwestorów. W obecnych warunkach kryzysowych rządy powracają do polityki ochrony krajowych przedsiębiorstw i wewnętrznego rynku pracy przed zagraniczną konkurencją. MFW w dalszym ciągu uznaje powyższe praktyki za szkodliwe. W Unii Europejskiej nie będzie zmian dotyczących zasad funkcjonowania wspólnego rynku, lecz istotnym problemem staje się opodatkowanie przedsiębiorstw dostarczających usługi świadczone spoza terytorium Unii.

Po trzecie, kryzys finansowy spowodowany agresywną polityką banków, przedsiębiorstw ubezpieczeniowych i funduszy inwestycyjnych ponownie postawił problem właściwego opodatkowania tego sektora. Liberalizacja przepisów dotyczących funkcjonowania sektora finansowego połączona z elastyczną polityką pieniężną była popierana przez MFW. Kryzys finansowy zmienił tę opinię. MFW popiera wprowadzenie obok polityki mikroostrożnościowej również politykę makroostrożnościową. Stabilizacja sektora finansowego, przede wszystkim ograniczenia prowadzenia ryzykownych operacji finansowych, skłania do zastosowania instrumentów podatkowych jako 
narzędzi ograniczających niebezpieczne dla stabilności sektora finansowego operacje. Ważną sprawą jest właściwy wybór i wdrożenie instrumentu odpowiedniego z punktu widzenia celu, jaki należy osiągnąć. W Polsce wprowadzono opodatkowanie aktywów sektora bankowego. Podatek ten służy głównie uzyskaniu dodatkowych wpływów budżetowych i nie ma zastosowania jako instrument ostrożnościowy.

Powyższa krótka lista wskazuje, że dyskusja na temat zmian systemu podatkowego będzie toczyć się dalej i MFW będzie w niej brał aktywny udział, gdyż świat, który był przedmiotem konsensusu waszyngtońskiego, istotnie się zmienił.

\section{BiBLIOGRAFIA}

Belka M., Krajewski S., Pinto B., Transforming State Enterprises in Poland: Evidence on Adjustment by Manufacturing Firms, World Bank Working Paper WPS1101, Washington 1993, https://doi.org/10.2307/2534605

Boughton J., From Suez to Tequila: The IMF as Crisis Manager, IMF Working Paper 1997, nr 90, Washington, https://doi.org/10.5089/9781451952001.001

Calvo G., Frenkel J., From Centrally Planned to Market Economies: The Road from CPE to PCPE, IMF Staff Papers 1991, t. 38, https://doi.org/10.2307/3867100

Cangiano M., Cottareli C., Cubeddu L., Pension Developments and Reforms in Transitional Economies, IMF Working Paper 1998, nr 151, Washington, https://doi.org/10.5089/ 9781451922912.001

Cordoba J., Gillingham R., Gupta S., Mansoor M., Schiller Ch., Verhoeven M., Equity and Efficiency in the Reform of Price Subsidies: A Guide for Policymakers, IMF Manuals and Guides, Washington 2000.

Daniel J., Davis J., Fouad M., Rijckghem C., Fiscal Adjustment for Stability and Growth, IMF Pamphlet Series nr 55, Washington 2006, https://doi.org/10.5089/9781589065130.054

Ebrill L., Chopra A., Christofides Ch., Mylonas P., Otker I., Schwartz G., Poland: The Path to a Market Economy, IMF Occasional Paper nr 113, Washington 1994, https://doi. org/10.5089/9781557754110.084

Ebrill L., Keen M., Bodin J.-P., Summers V., The Modern VAT, IMF, Washington 2001, https://doi.org/10.5089/9781589060265.071

Fischer S., Gelb A., Issues in Socialist Economy Reform, „Journal of Economic Perspective” 1991, t. 5, nr 4, https://doi.org/10.1257/jep.5.4.91

Guitian M., The Unique Nature of the Responsibilities of the International Monetary Fund, IMF Pamphlet Series nr 46, Washington 1992, https://doi.org/10.5089/9781557753212.054

Gupta S., Honjo K., Verhoeven M., Transition Economies: How Appropriate Is the Size and Scope of Government?, „Comparative Studies” 2001, t. 45, nr 4, https://doi. org/10.1057/palgrave.ces.8100014

Gupta S., Keen M., Clements B., Mello L., Mani M., Fiscal Dimensions of Sustainable Development, IMF Pamphlet Series nr 54, Washington 2002. 
Harrison G., Krelove R., VAT Refunds: A Review of Country Experience, IMF Working Paper 2005, nr 218, Washington, https://doi.org/10.5089/9781451862379.001

International Monetary Fund, Articles of Agreement, Washington 1993.

International Monetary Fund, The EU Fiscal Framework and Pension Reform, [w:] Central and Eastern Europe, New Member State Policy Forum, Country Report 15/98, IMF, Washington 2015.

International Monetary Fund, Financial Crises: Characteristics and Indicators Vulnerabilities, World Economic Outlook, IMF, Washington 1998.

International Monetary Fund, Republic of Poland, Country Report 92/139, IMF, Washington 1992.

International Monetary Fund, Republic of Poland, Country Report 97/41, IMF, Washington 1996.

International Monetary Fund, Republic of Poland, Country Report 98/53, IMF, Washington 1998, https://doi.org/10.5089/9781451812015.002

International Monetary Fund, Republic of Poland, Country Report 04/217, IMF, Washington 2004, https://doi.org/10.5089/9781451831863.002

International Monetary Fund, Republic of Poland, Country Report 06/391, IMF, Washington 2006, https://doi.org/10.5089/9781451831993.002

International Monetary Fund, Republic of Poland, Country Report 14/173, IMF, Washington 2014, https://doi.org/10.5089/9781498389938.002

International Monetary Fund, Republic of Poland - Recent Economic Developments, Country Report 97/54, IMF, Washington 1997, https://doi.org/10.5089/9781451831795.002

International Monetary Fund, Republic of Poland - Selected Issues, Country Report 99/52, IMF, Washington 1997, https://doi.org/10.5089/9781451831818.002

International Monetary Fund, Republic of Poland - Selected Issues, Country Report 00/46, IMF, Washington 2000, https://doi.org/10.5089/9781451813517.002

International Monetary Fund, Republic of Poland - Selected Issues, Country Report 00/60, IMF, Washington 2000, https://doi.org/10.5089/9781451831887.002

International Monetary Fund, Republic of Poland - Selected Issues, Country Report 11/167, IMF, Washington 2011, https://doi.org/10.5089/9781455295722.002

International Monetary Fund, Republic of Poland - Selected Issues and Statistical Appendix, Country Report 98/62, IMF, Washington 1998, https://doi.org/10.5089/9781451800616.002

International Monetary Fund, Technical Assistance Report - Tax Administration Challenges and Strategic Priorities, Country Report 15/112, IMF, Washington 2015, https://doi. org/10.5089/9781498396493.002

Kołodko G., Equity Issues in Policy Making in Transition Economics, [w:] Economic Policy and Equity, red. V. Tanzi, IMF, Washington 1999.

Krueger A., A Continuous Adventure: The Pursuit of Stability and Growth in Modern Economies, Distinguished Lectures Series nr 18, Akademia Leona Koźmińskiego, Warszawa 2006.

Lipton D., Sachs J., Creating a Market Economy in Eastern Europe: The Case of Poland, „Brookings Papers in Economic Activity” 1990, t. 1, https://doi.org/10.2307/2534526

Lipton D., Sachs J., Privatization in Eastern Europe: The Case of Poland, „Brookings Paper of Economic Activity” 1990, t. 2, https://doi.org/10.2307/2534508 
Ministerstwo Finansów, Biała księga podatków. Analiza obecnego systemu podatkowego. Propozycje zmian, Warszawa 1998.

Ministerstwo Finansów, Odpowiedź na interpelację poselską 19430/2010 w sprawie możliwości odliczania kosztów reformy emerytalnej od długu publicznego, Warszawa 2010.

Mundell R., Do Exchange Rates Work? Another View, IMF Working Paper 1991, nr 37, Washington, https://doi.org/10.5089/9781451977769.001

Musa M., Savastano M., The IMF Approach to Economic Stabilization, IMF Working Paper 1999, nr 104, Washington, https://doi.org/10.5089/9781451852745.001

Norregaard J., Khan T., Tax Policy: Recent Trends and Coming Challenges, IMF Working Paper 2007, nr 274, Washington, https://doi.org/10.5089/9781451868371.001

Roaf J., 25 years of Transition Post-Communist Europe and the IMF, Regional Economic Issues Special Report 10/2014, IMF, Washington 2014, https://doi.org/10.5089/ 9781498305631.086

Sachs J., Poland's Jump to the Market Economy, Cambridge, MA 1993, https://doi. org/10.7551/mitpress/5430.001.0001

Tanzi V., Howell Z., Fiscal Policy and Long-Run Growth, IMF Working Paper 1996, nr 119, Washington, https://doi.org/10.5089/9781451854121.001

Tanzi V., Howell Z., Tax Policy for Emerging Markets: Developing Countries, IMF Working Paper 2000, nr 35, Washington, https://doi.org/10.5089/9781451845341.001

Williamson J., What Washington Means by Policy Reform, [w:] Latin American Adjustment: How Much Has Happened?, Washington 2002.

\section{Recommendations of the International Monetary Fund IN THE PROCESS OF POLISH TAX SYSTEM REFORMS}

Summary. The successful economic transition from centrally planned economy into free market system required a total transformation of a tax framework. From the beginning the IMF assisted Poland with technical advice and formulated recommendations in the reports. The paper outlines how the Polish authorities were supported by the IMF and how far the Polish reforms were shaped by the model known as the Washingtonian consensus. The IMF's advice for a tax reform should be analysed as an integrated part of a transformation process. The paper scrutinises which IMF's recommendations were adopted by Polish authorities and why some tax system changes were far from the best practises underlined by the IMF. Although the IMF's focus on tax matters was phasing out since Polish membership in the European Union the IMF's technical support was still invaluable in a field of tax administration. In the paper the case of the last VAT tax administration reform is assessed from the perspective of the recommendations of the IMF technical mission. The last part of the paper is devoted to the analysis of challenges of the future collaboration in the field of taxation with the IMF.

Keywords: economic transition, International Monetary Fund, tax reform, Washingtonian consensus, tax administration 